\title{
経頭蓋法による外側翼突筋の解剖学的観察ならびに文献的考察
}

\author{
杉崎正志・小守英一・中沢正博・田辺晴康 \\ 加藤 征*
}

\section{Anatomical studies of the lateral pterygoid muscle by the superior approach and a review of the literature}

\author{
Masashi Sugisaki $\cdot$ Eiichi Komori $\cdot$ Masahiro Nakazawa $\cdot$ Haruyasu TANabe \\ Susumu Kato*
}

\begin{abstract}
There have been a number of physiological and anatomical reports on the lateral pterygoid muscle. They include some unclear points, and no agreement has been reached from the results so far. Most of the pevious studies have been performed by the lateral approach. Few reports have been made by the superior approach which is useful for investigation of the muscle.

We dissected 26 temporomandibular joints from 14 adult cadavers by the superior approach and studied the muscle, as well as its functions, reviewing the literature.

The lateral pterygoid muscle varied with the cadaver in the number of the head as follows; $7.7 \%$ of all specimens had single head, $3.8 \%$ had the lateral and medial heads, $57.6 \%$ had the superior and inferior heads, and $30.7 \%$ had three heads, i.e. superior, inferior and medial. This result indicates that the lateral pterygoid muscle was substantially different from cadaver to cadaver. The muscle fibers were so crowded with each other and with those of the temporal muscle that only 8 cases had the superior and inferior head's muscle which could be completely separated from each other. The superior head laid at an angle of 7.0 degrees medially with respect to the line perpendicular to the horizontal long axis of the mandibular head, the inferior head was at an angle of $19.1^{\circ}$, and the medial head was at an angle of about $37.7^{\circ}$ to this reference line, on average. The superior head of the muscle was attached to the pterygoid fovea of the mandibular head except that the superficial layer of the superior head was attached to the inferior surface of the disk. The medial head of the muscle appeared to be inserted into the medial border of the disk and the medial capsule. In addition to the lateral pterygoid muscle, the temporal muscle of some specimens were attached to the anterosuperior stratum of the disk through the fibrous tissues and, sometimes, directly to the anterolateral part of the disk.

We support, in principle, the previous reports that the lateral pterygoid muscle has generally two heads. We observed that, however, many variations of the muscle existed in terms of the individual their age, and their sex, and that the muscle fibers considerably crossed each
\end{abstract}

東京䋇惠会医科大学附科学教室

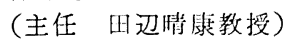

* 東京慈惠会医科大学解剖学教空 （主任：山下 公教授）

Department of Odontology, The Jikei University

School of Medicine (Chief: Prof. Haruyasu
Tanabe)

* Department of Anatomy, The Jikei University School of Medicine (Chief: Prof. Hiroshi Yamasita)

受付日：昭和61年 1 月 27 日 
other. Therefore, although we cannot deny the possibility that the superior head and inferior head of the lateral pterygoid muscle would function differently, we do not support that the superior and inferior heads of the muscle move antagonistically on electromyogram.

Key words: lateral pterygoid muscle, anatomy, temporomandibular joint

\section{緒}

言

外側翼突筋は下䪽頭や関節円板の連動に関与し，顎運 動や顎関節症において，きわめて重要な筋であるといわ れている1). 外側翼突筋に関する生理学的あるいは機能 解剖学的報告は比較的多くあるが，いまだ不明な点が多 く，結果が一致しない，筋の機能を究明するに当り，そ の能や周囲組織の解剖学的特徵を明らかにすることは重 要なことであるか゚，外側翼突筋に関する過去の報告は， そのほとんどが外側からの観察で，筋の走行や隣接諸組 織との関係について検索するのに最適である経頭蓋法に よる観察は少い2,3).わたくしたらは経頭蓋法によって 外側翼突筋を観察する機会を得, 外側翼突筋の走行, 筋 頭数，側頭筋と外側翼突筋との交錯ならびに関節円板へ の付着筋について検索し，その機能を含め，文献的考察 を行ったので報告する。

\section{観 察 材 料}

観察材料には東京慈恵会医科大学系統解剖学実習用の 表 1 観察材料

\begin{tabular}{|c|c|c|c|c|c|c|}
\hline & 性 & 年畧会 & 䚁察側 & 残存歯式 & & 岛の \\
\hline No. 1 & $\mathbf{M}$ & 60 & 左・右 & $\frac{6-3 \mid 45}{3+3}$ & & 明 \\
\hline No. 2 & $\mathbf{M}$ & 91 & 左・右 & 無歯顎 & 不 & 明 \\
\hline No. 3 & $\mathbf{M}$ & 53 & 左・右 & $\frac{762 \mid 3-57}{7+5}$ & 不 & 明 \\
\hline No. 4 & $\mathbf{M}$ & 94 & 左・右 & $\frac{2+1}{3 \mid 4-7}$ & 使 & 用 \\
\hline No. 5 & $\mathbf{M}$ & 85 & 左・右 & 無㐘顎 & 不 & 明 \\
\hline No. 6 & $\mathbf{M}$ & 60 & 左-右 & $\frac{64 \mid 6}{541+4}$ & 使 & 用 \\
\hline No. 7 & M & 44 & 左- 右 & $\frac{6-3 \mid 4-8}{8+8}$ & 使 & 用 \\
\hline No. 8 & $\mathbf{M}$ & 不明 & 左 & 不 明 & 不 & 明 \\
\hline No. 9 & $\mathbf{M}$ & 不明 & 左 & 不 明 & 不 & 明 \\
\hline No. 10 & $\mathbf{M}$ & 53 & 左 - 右 & 無遴靧 & 不 & 明 \\
\hline No. 11 & $\mathbf{M}$ & 61 & 左-右 & 無霜顎 & 不 & 明 \\
\hline No. 12 & F & 70 & 左・在 & 無菌顎 & 使 & 用 \\
\hline No. 13 & $\mathbf{M}$ & 41 & 左・右 & $\frac{7-2 \mid 457}{7+7}$ & 使 & 用 \\
\hline No. 14 & $\mathbf{M}$ & 77 & 左 - 右 & 無粨顎 & 使 & 用 \\
\hline
\end{tabular}

成人屍体14体26側を用いた，屋体は 1 体のみ女性で，他 は男性であった，年跉，観察側，残存歯敊上び義崡の有

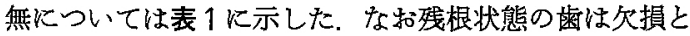
して扱った。

\section{観 察 方 法}

\section{観察項目}

下記の項目について観察した。

1）外側翼笑筋の筋頭数特よび走行について

2）側頭筋と外側翼突筋との交錯について

3）関節円板に付着する筋について

\section{観察方法}

1962 年 Pinto ${ }^{4)}$ の報告による経頭蓋法 (Superior approach）に準じて行った。まず，頭蓋底内面を露出す

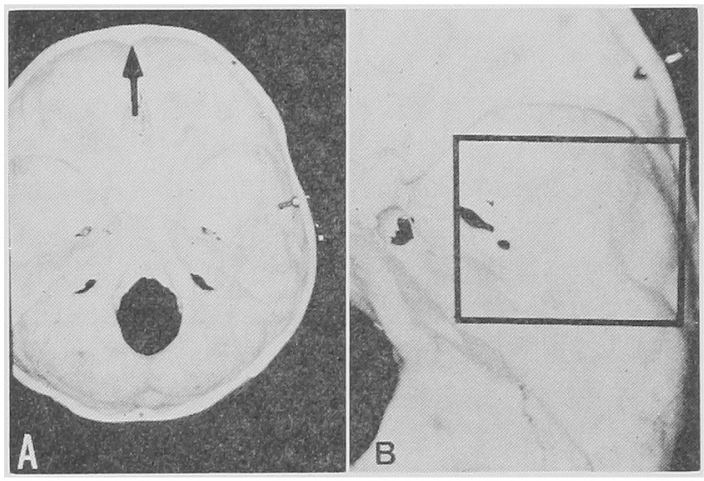

写真 1- $\mathbf{A}, \mathbf{B}$ 矢印は前方を示す

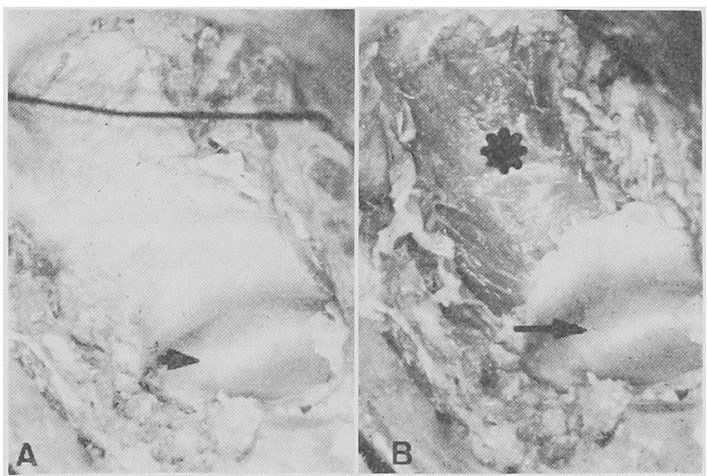

写真 2-A， B 矢印怡関節门板を，*印は外側翼㔖 笳を示す。 


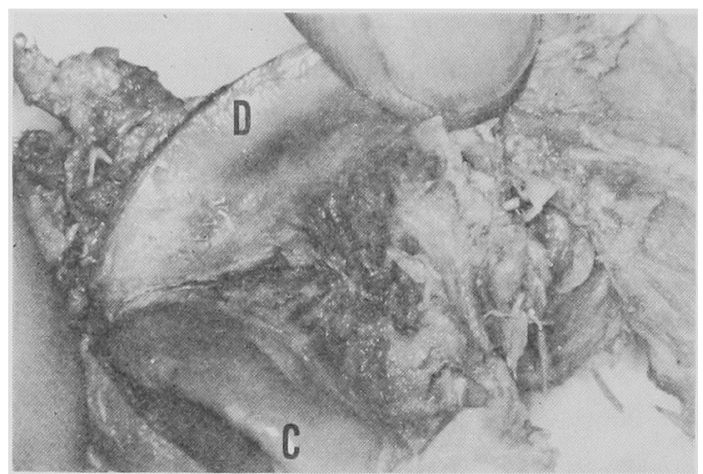

写真 3 関節円板を前方に翻転時の所見 $\mathrm{C}:$ 下額頭 $\mathrm{D}:$ 関節円板

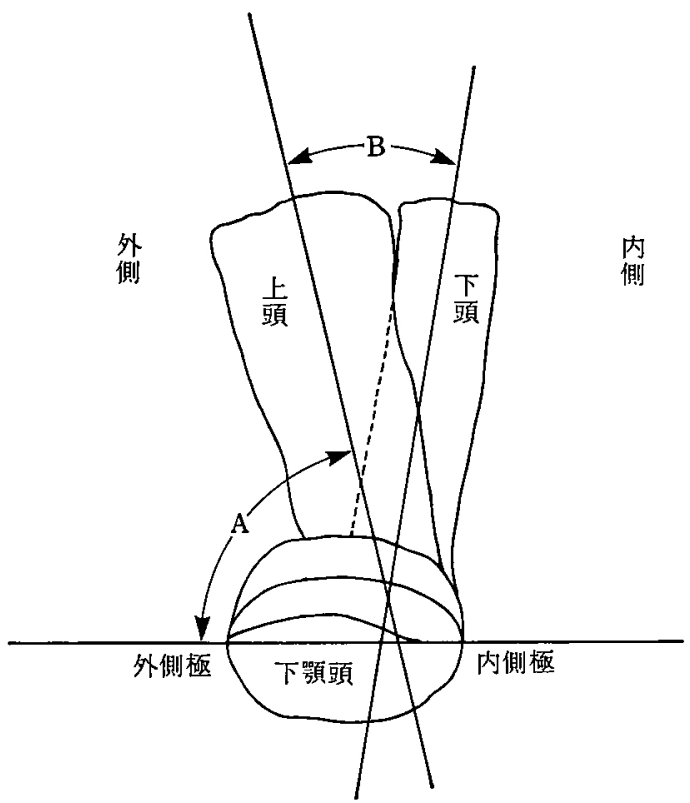

図 1 外㑡翼突筋の角度的計測 A：各筋嘼と下顎頭のなす角度 $\mathrm{B} ：$ 上下頭のなす角度

る. 次いで中頭蓋䈪において側頭骨と蝶形骨の一部を四 角形に除去する。 この際, 後方は内耳孔拈よび外耳孔を 結ぶ仮想線，内側恃内耳孔と卵円孔外側を結ぶ仮想線と する，前方拉よび外側は必要に応じ側頭筋との関係, 外 側翼突筋の起始部が 明らかになる 部位とする（写真 1$\mathbf{A}, \mathbf{B}$ )。この中頭蓋窝を除去すると結合織，側頭筋，関 節円板，中耳などが現れる（写真 2-A）。ついでこの結 合織㧍よび蝶形骨まで入り込んだ側頭筋を除去すると外 側翼突筋が現れる (写真 2-B). また側頭筋と外側垡突 筋中関節円板との関係を明らかにするため，側頭骨，結 合織および関節円板前延長部の一部を除去する。ささらに
表 2 外側望突筋の笳頭数

\begin{tabular}{|c|c|c|}
\hline 1 頭筋 & & 2例 \\
\hline \multirow[t]{2}{*}{2 㽬筋 } & 外側頭／内側頭 & 1例 \\
\hline & 上頭／下頭 & 15例 \\
\hline 3 頭筋 & 上頭 /下頭／内側頭 & 8例 \\
\hline
\end{tabular}

表 3 上頭が独立した走行を示したもの

\begin{tabular}{ll}
\hline 2 頭筋 & 7 例 \\
3 頭筋 & 1 例 \\
\hline
\end{tabular}

表 4 外側翼乫笳各筋頭と下顎頭とのなす角度

\begin{tabular}{c|rcc}
\hline 筋 頭 & MEAN & SE & N \\
\hline 上 頭 & $97.0^{*}$ & 2.21 & 23 \\
下 頭 & $109.1^{*}$ & 2.55 & 23 \\
内側頭 & $127.7^{*}$ & 4.03 & 8 \\
\hline
\end{tabular}

* $1 \%$ \%危險率で有意差あり 単位 : 度

表 5 上頭と下頭のなす角度

\begin{tabular}{ccc|ccc}
\hline \multicolumn{2}{c|}{ 上下頭が交錯していた群 } & \multicolumn{3}{|c}{ 上下頭が独立分離していた群 } \\
\hline MEAN & SE & N & MEAN & SE & N \\
8.1 & 2.24 & 17 & 17.8 & 4.79 & 8 \\
\hline
\end{tabular}

単位：度

関節円板を下䫇頭頂部付近で外側極と内側極とを結ぶ仮 想線上で前後に 2 分割し, 前方の円板を翻転し, 関節円 板に付着する筋を観察した（写真了）．経頭蓋法による 観察後, 外側巽㔖筋, 下類頭, 関節円板, 側頭筋などを 一塊之して取り出し, 前後方向, 内外側方向より外側翼 突筋の筋頭数，走行ならび側頭筋との関係などを観察 した。また，外側翼突筋ならびに下顎頭内側極就よび外 側極を剖出後, 顔耳平面に平行に頭頂側より写真撮影を 行い，下罘頭長軸（下顎頭内側極扣よび外側極を結ら゙直 線）に対する 外側瑟笑筋各筋頭の 角度を計測した。 た 扣，各等頭の角度は起始部および停止部に於ける筋腹中 央部を結ぶ仮想線を用いた（図1）。

$$
\text { 結果 }
$$

1）外側翼突筋の筋頭数および走行について

外側翼突筋起始部から中央部付近にかけて上下あるい は内外側などに比較的分離可能な筋頭,すなわち，上下 頭間に脂肪, 䫑動脈, 頓神経などの介在物が存在し, か つ比較的分離可能なるのをそれそ゚れ 1 頭として数克た。 筋頭数は表 2 のごとく，外側翼突筋が 1 頭筋であったも 


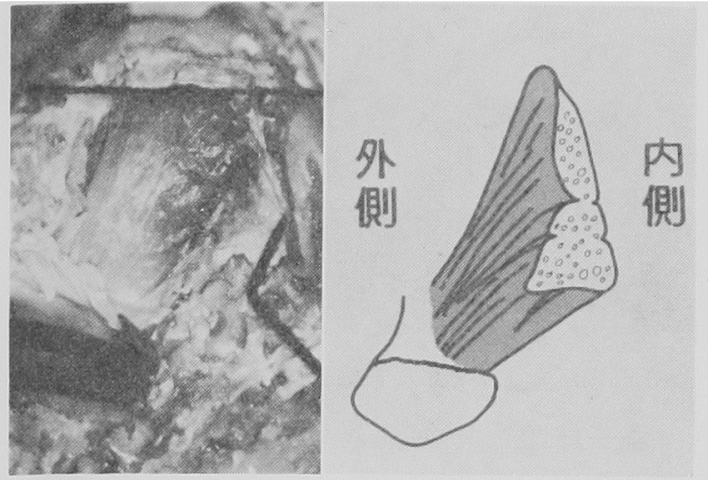

写真 41 頭筋例の経頭蓋法による所見ならびにシ エーマを示す。

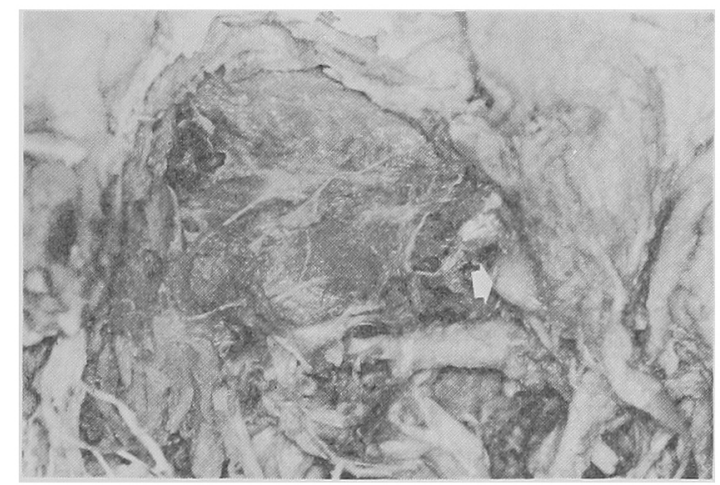

写真 51 頭筋例の外側からの所見を示す。知印は 下顎頭頸部切断面を示す

の 2 例，外側扣よび内側頭の 2 頭筋であったもの 1 例， 上頭, 下頭の 2 頭筋であったもの15例, 上頭, 下頭, 内 側頭の 3 頭筋であったもの 8 例であった（表 2). また， 筋走行中に上頭が他の筋からほぼ独立した走行を示した るのは 8 例に見られたが，他は走行中にそれぞれの筋頭 西るいは側頭筋と比較的多くの筋線維が交錯を示してい

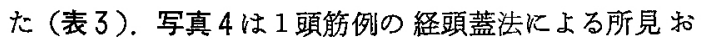
よびそのシェーマを, 写真 5 は同標本の外側からの所見 を示している。外側からの観察では上下 2 頭筋様であっ たが，上下頭の㔀離は起始部外側ですでに困難で，上下 頭間に脂肪などの介在物む見られなかった，上下頭が独 立分離していた 2 頭筋例では，薄い上頭と，その下に下 頭が異なった角度を有してみられた（写真 6 ）。しかし 2 頭筋例の過半数は外側からの観察では途中まで 2 頭に 分離可能であったが，前方あるいは内側からの観察では 下頭之の間飞筋線維の交錯が比較的多く認められた（写 真 7-A， B， 8-A, B). 3頭筋例では, 上頭, 下頭およ びその内側に内側頭か゚みられたが，それぞれの完全分離 は困難であった（写真 9）。写真10-A は関節円板を前方 に展開したところで，下顎頭後縁にまで入り込んだ，大

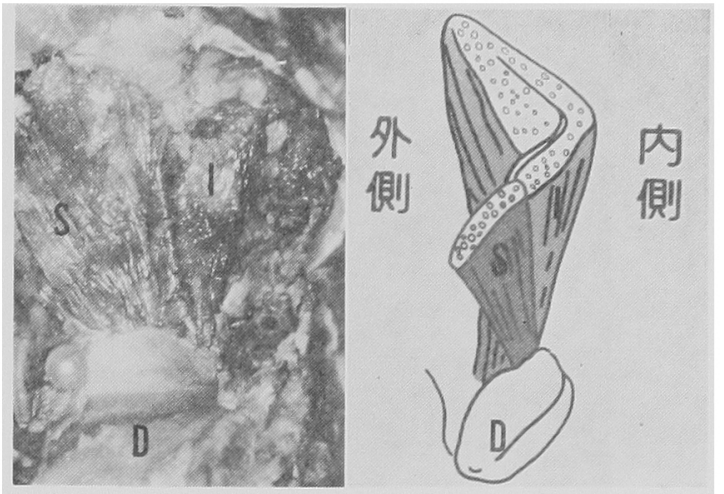

写真 62 頭筋例で上下頭が独立分離していた例 でその経頭蓋法による所見ならびにシ エーマを示す。

$\mathrm{D}$ ：関節円板 $\mathrm{S}$. 上頭 $\mathrm{I}$ ：下頭

表 6 関節円板に付着する筋

\begin{tabular}{|c|c|}
\hline 外側㛀突筋上頭一関節 円板前内側 & 23例 \\
\hline 外㑡翼突筋内側頭一関節円板内㑡端 & 5例 \\
\hline 㑡頭筋一関節円板前延長部 & 5例 \\
\hline 側頭筋一関節円板前外側 & 12 例 \\
\hline
\end{tabular}

きな内側頭が諗められた。しかし外側からの観察では， 内側頭は確認できなかった（写真 10-B）. 写真 11 は,

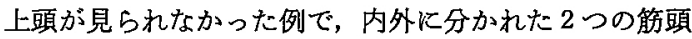
がみられ，内側頭の上部が円板の内側に付着しているの が見られた。

上頭，下頭，括上び内側頭の下罘頭長軸に対する角度 計測は 1 頭筋例ならびに内外側 2 頭筋例を除いた23例に ついて行った，その結果，各筋頭の下靧頭長軸に対する 角度は上頭は 97.0 度, 下頭は 109.1 度, 内側頭は 127.7 度とそれぞれ有意差をもって見られた（表 4 ）。また，上 下頭が独立分離していた群と，交錯していた群との間に は各筋頭の角度に有意差は見られなかったが，上下頭が 独立分離していた群の方が交錯していた群より上下頭間 のなす角度が大きい傾向が見られた（表 5 ）。

2）側頭筋と外側翼突筋との交錯

外側翼突筋上の結合織を除去すると側頭筋が外側翼突 筋と交錯しているのが見られた（写直 12）．屍体は㬰習 用のため比較的観察部の保存状態が良好なものを選んた が側頭筋の損傷が著しかった 1 体 2 側は除外した．側頭 筋と外側翼突筋との交錯は上頭とであり，24例中12例に 筇線維量は少ないが交錯が見られた，写真13，写真14K 外側翼突筋に交錯した側頭筋を示す。をた，外側からの 所見で側頭筋が外側翼突筋上頭のごとく走行し，下顎頸 に停止していたものか゚見られた（写真15-A）。これを除 去すると外側翼突筋上頭が明らかになった（写真15-B).

3）関節円板に付着する筋の観察 


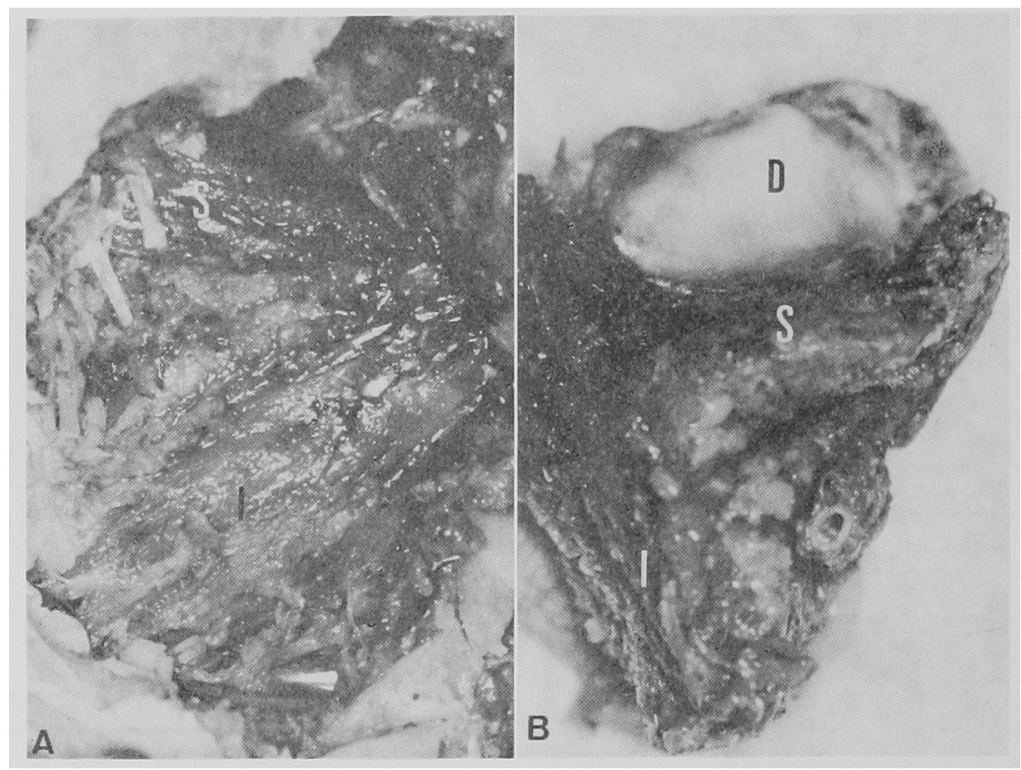

写真 7-A， B 2 頭筇例で上下頭の交錯していた例

7-A：外㑡からの所見

7-B：前方からの所見では上下頭は交錯している。

$\mathrm{D}$ ：関節円板 $\mathrm{S}$ ：上頭 $\mathrm{I}:$ 下頭

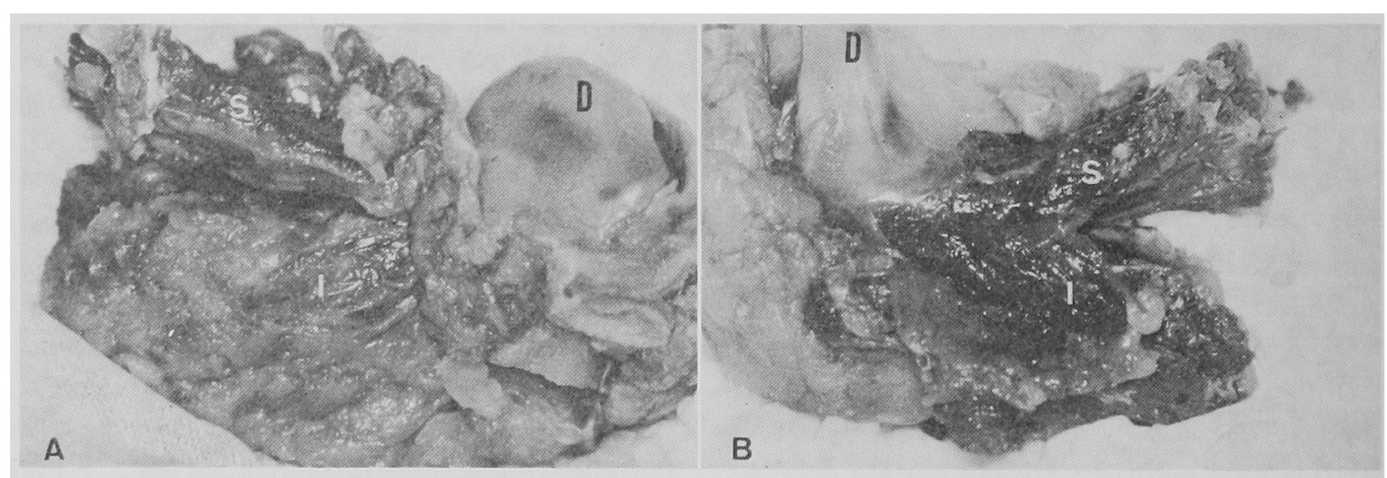

写真 8-A, B 2 頭筋例で上下頭の交錯していた例

8-A:外側からの所見

8-B：内㑡からの所見では上下頭は交錯している.

$\mathrm{D}$ ：関節円板 $\mathrm{S}$ ：上頭 $\mathrm{I}$ ：下頭

関節円板には外㑡翼突筋上頭, 内側頭, 側頭筋が付着 しているのが見られた（表 6). その付着状態は組織学 的には確実ではないが，外侧翼突筋上頭は主に上頭上縁 が関節円板中央から内側にかけて円板の下面に付着し， その他は翼突筋䔰に停止乙（写真 16），内側頭は一部円 板内側端に直接入り込んでいた（写真 17）. また，側頭 筋は結合織をもって関節円板前正長部に付着するものや （写真 18），直接関節円板前外側に付着していた（写真 19．このように侧頭筋と関節円板との間に関連が見ら
れたものは24例中17例であった（表 3 )。

考察

\section{1）外側翼突筋の頭数および走行について}

ヒトの外側翼突筋は1870年 Quain 解剖学 ${ }^{5)}$ 飞おいて, すでに上下部に分けられており，上部は関節円板に向 い，下部は下䫟頸に付着すると記載されている。ささらに 1906年 Chissin ${ }^{6)}$ 以降, 一般的に, 外側翼突筋は上頭お 


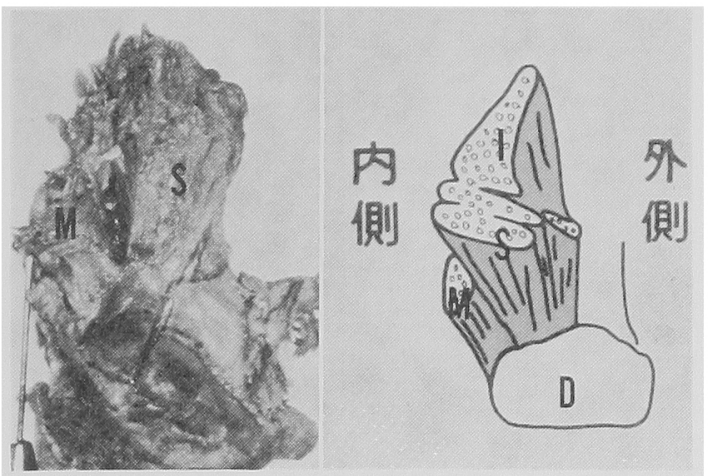

写真 93 頭能例の経頭蓋法による所見ならびにシ ェーマを示す。

$D$ ：関節 $\mathrm{F}$ 板 $S$ ：上頭 $I$ ：下頭 $M$ ：内側頭

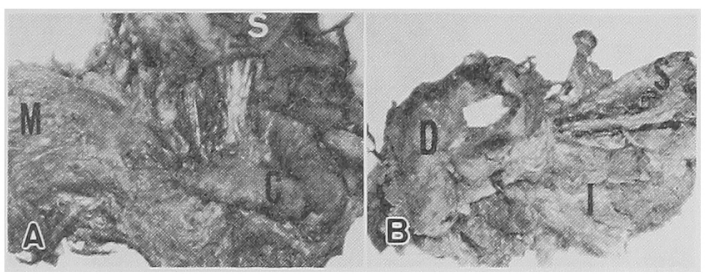

写真 10-A, B 3 頭筋例

10-A：関節円板を前方に翻転時の所見

$10-\mathrm{B}:$ 外側加 5 所見

$\mathrm{D}$ ：関節円板 $\mathrm{C}$ ：下顎頭 $\mathrm{S}$ ：上頭 $\mathrm{I}$ ：下頭 $\mathrm{M}$ ：内側頭

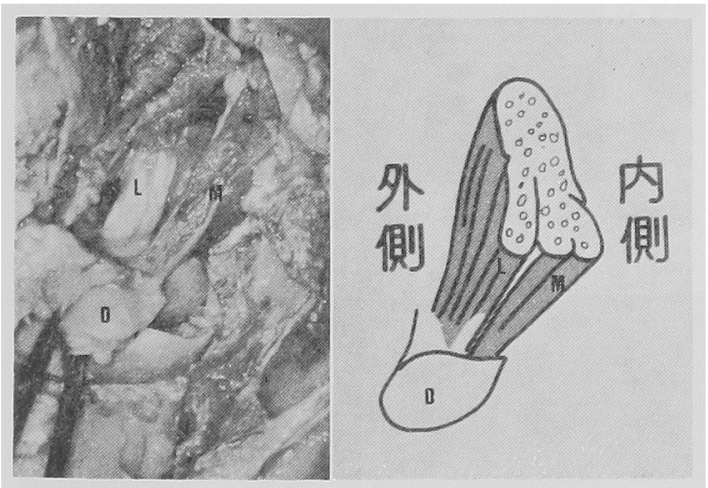

写真 11 内外 2 頭筋例の経頭蓋法による所見なら びにシェーマを示す。

$\mathrm{D}$ ：関節円板 $\mathrm{L}$ ：外側頭 $\mathrm{M}$ ：内側頭

よぴ下頭の 2 頭筫で，上頭は薄く，小さく，蝶形骨大翼 側頭下面より起こり後下方に向い，関節円板に付く，下 頭は厚く，大きく，蝶形骨翼状突起外側板外面上り，後 上方に向い，下顎頸に付着するといわれている7 11). し かし，一部の解剖学の成書では外側翼突筋をひとつの筋 として記載している122。 また，外側翼笑筋を内外側の二

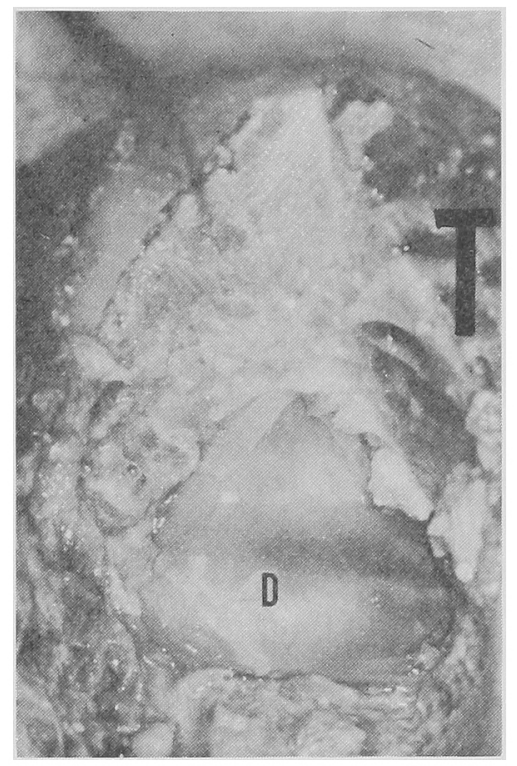

写真 12 側頭筋と外側翼突筋との交錯を示す

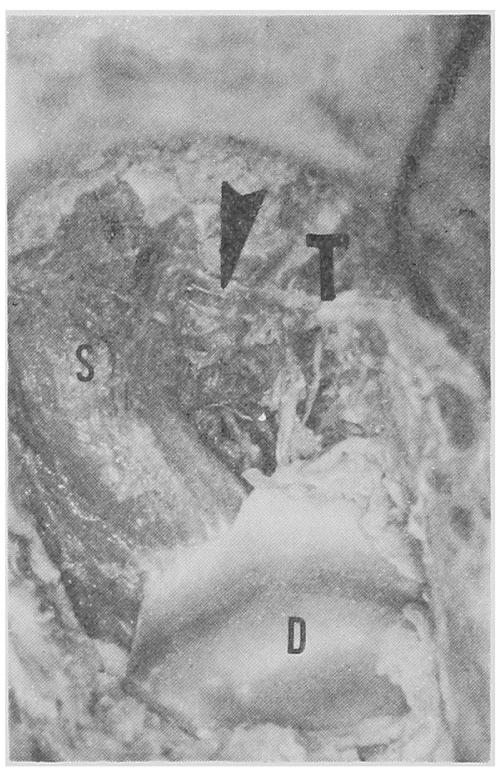

写真 13 㑡頭筋と外側翼突筋との交錯を示す。 矢印㹥交錯部位を示す。

$\mathrm{T}$ ：側頭筋 $\mathrm{D}$ ：関節円板 $\mathrm{S}$ ：上頭

頭筋之記述している成書も見られる ${ }^{13)}$ 。さらに，外側翼 突筋において 3 頭筋の存在を示した報告もある 中山 $(1932)^{14)}$ は中国人50体100側飞おいて，外側翼突筋 を肉眼的観察し，その結果，2頭をむって起こるもの は83\%，3頭をもって起こるものは17\%であった．鈴木 $(1941)^{15)}$ は日本人10体20側に打いて，2頭をるって起こ 


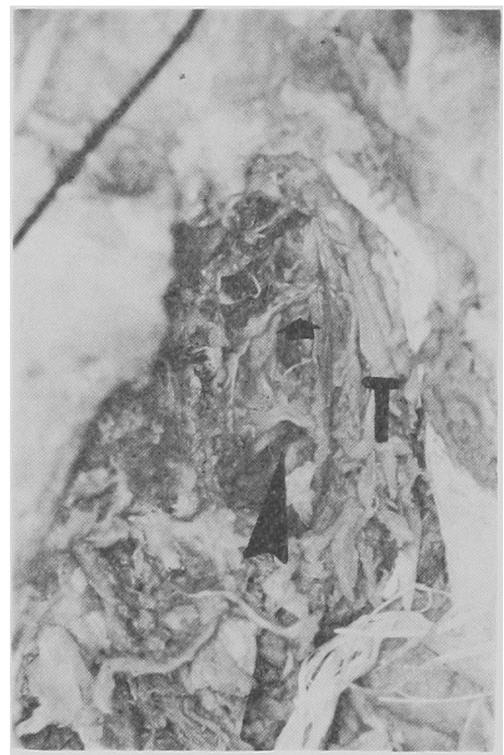

写真 14 外㑡からの所見で側頭筋 $(T)$ と外㑡 翼突筋々の交錯を示す。矢印は交錯部 位を示す。

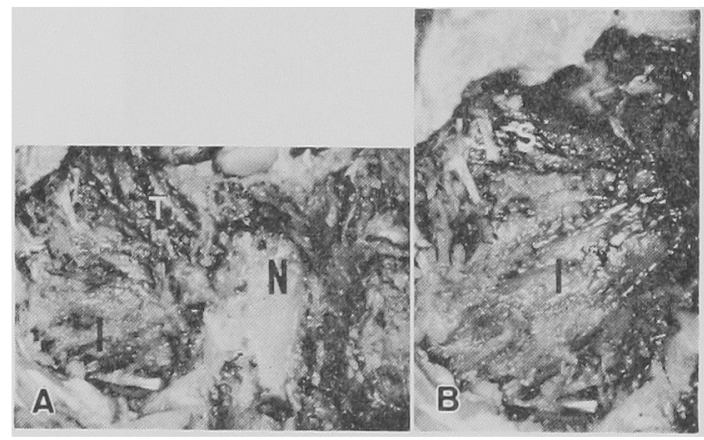

写真 15- A, B 㑡頭筋の異常走行例（外側からの 所見)

$\mathrm{T}$ ：㑡頭筋 $\mathrm{N} ：$ 下顎頸 $\mathrm{S} ：$ 上頭 $\mathrm{I}$ ：下頍

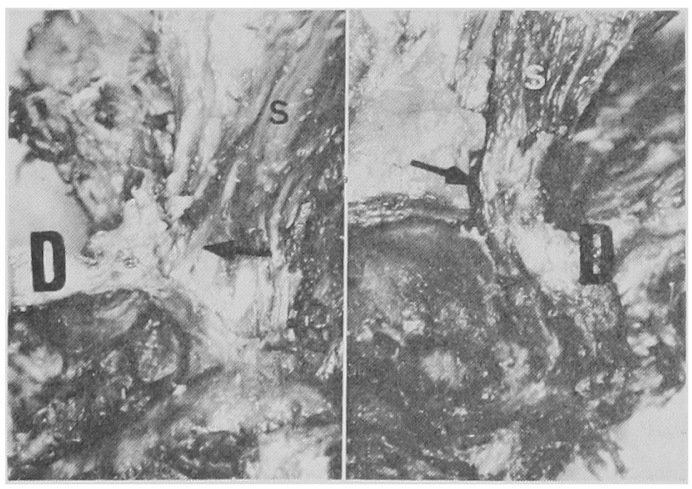

写真 16 上頭と関節円板の関係を示す. $\mathrm{S}$ : 上頭 $\mathrm{D}$ : 関節円板

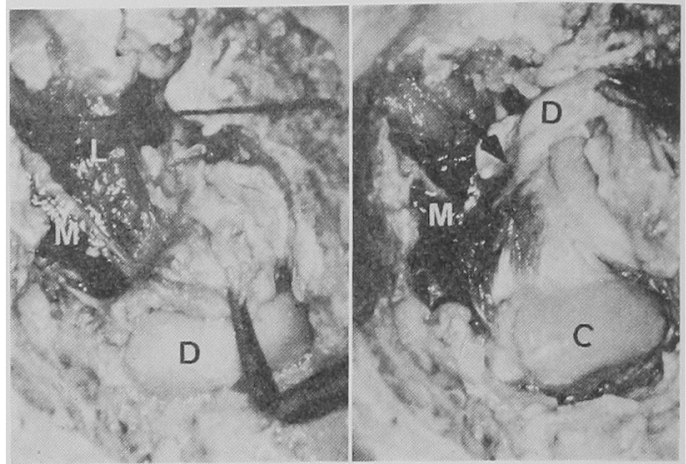

写真 17 内側頭と関節円板との関係を示す (知印). $\mathrm{D}$ ：関節 円板 $\mathrm{L}$ ：外側頭 $\mathrm{M}$ ：内㑡頭 $\mathrm{C}$ ：下額頭

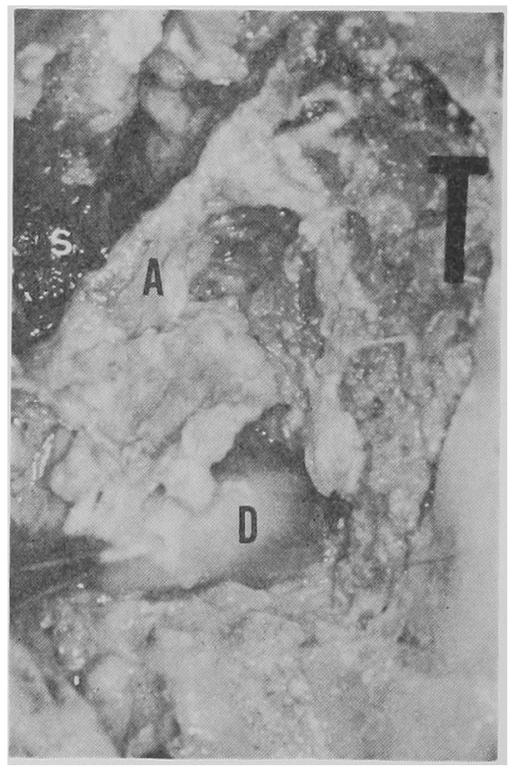

写真 18 㑡頭笳（T) と関節円板前延長部との 関係を示す。

$\mathrm{T}$ : 側頭筇 $\mathrm{S}$ ：上頭 $\mathrm{A}$ ：関節円板前延長部 $\mathrm{D}$ ：関節円板

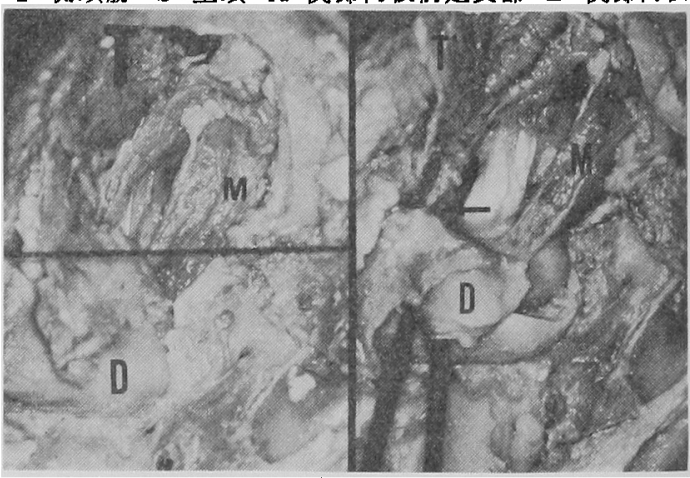

写真 19 側顽筋（T）および内側頭と関節円板 との関係を示す。

$\mathrm{T}$ : 㑡頭筋 $\mathrm{D}$ : 関節円板 $\mathrm{M}$ ：内側頭

矢印：関節円板前外側に付溏する側頭筋を示す 
るものは $90 \% ， 3$ 頭をもって起こるものは $10 \% て ゙ ，$ 岩田 (1959) ${ }^{16)}$ は日本人59体において，1頭をもって起こるも のは右側 $1.9 \%$, 左側 $3.5 \%, 2$ 頭をもって起こるもの は, 右側 $92.1 \%$, 左側 $82.2 \%, 3$ 頭をもって起こるも のは右側 $5.9 \%$, 左側 $14.3 \%$ であったと述べている. Troiano (1967)2) は経頭蓋法によって外側翼突筋を観察 し, 上下 2 頭以外飞筋膜で被覆された内側頭を認め, さ らに上頭を浅束と深束とに分けている. このように外側 翼突筋の筋頭数に関する解剖学的報告は比較的多く見ら れるが，いまだ一致を見ない．

わたくしたちの観察では外側翼突筋が 1 頭筋であった ものが7.7\%, 上頭, 下頭の 2 頭筋であったもの $57.6 \%$, 外側および内側頭の 2 頭筋であったもの $3.8 \%$, 上頭, 下頭, 内側頭の 3 頭筋であったもの $30.7 \% て ゙ ， 2$ 頭筋が 最も多く, 全体の過半数を占め, 外側翼突筋は一般的に 上下 2 頭筋であるという従来の 報告に一致した。しか し， 1 頭筋あるいは 3 頭筋が存在し，また 2 頭筋にお いても内外側に分かれていた例もあった。 これら筋頭 数の違いについて考察した報告はほとんぞ見られず, Troiano (1967)2) が内側頭は胎生期に批いて㗓骨に付着 している外側翼突筋の残遺であるうと考察しているにす ぎず，単に破格として扱っているのが現状である，わた くしたちの観察で 3 頭筋例が比較的多く見られたのは観 察方法の違いによるるのと思われた。すなわち, 先に述 べたよらに, 外側からの観察では内側頭は観察し得ない ためである. また，上頭の欠如例に関しては内側頭が関 節円板に付着していることより内側頭が上頭の代わりを しているものと考えられるが，その理由については不明 であった.

外側翼突筋の走行について, 中山 (1932) ${ }^{14)}$ は, 付着 部において $63 \%$ は両頭が痹着する。鈴木 $(1941)^{15)}$ は 付着部において両頭が癒着するもの，まったく独立し ているもの，交差するものがそれぞれ見られる，岩田 $(1959)^{16)}$ は上下頭の筋束の走行パターンを 18 型に分類 し，これらの中で，筋走行中に上下頭の交錯が見られる ものは右側で $14 \%$ ，左側で $22.3 \%$ でった．DuBrul $(1980)^{18)}$ は $2 つ の$ 筋頭は起始部では分かれているが, 関 節の前方部で癒合し，それは人為的にのみ分離可能であ ると述べている。しかし, Christensen (1969) ${ }^{10)}$, Honée

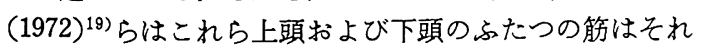
ぞれ筋膜で被覆され，停止部においてすら分離可能であ ると記述している。 また, Honée (1972) ${ }^{19)}$ は上頭およ び下頭は矢状面に対しそれぞれ 26 度と 45 度の角度を有 し, フランクフルト平面に対してはそれぞれ 23 度と10度 であったと述べている.

わたくしたちの観察では, 外側からは 2 頭筋として見 られたことが多いが, 筋走行中に上下頭がほぼ完全に独 立した走行を示したものは 8 例にすぎず，他は走行中に それぞれの筋頭あるいは側頭筋と比較的多くの筋線維が
交錯を示していた. しかもこの 8 例においても，下頸頸 前方部では嘴合していた。 上頭と下頭との交錯は，主に 内側部および下顎頸前方部で多く見られたが，1頭筋を 示した例は起始部外側においても交錯がみられ，上下頭 に分離は困難であった。な打上頭が確認できなかったも のが 1 例にみられた。これら筋頭数扣よび筋線維の交錯 に関する考察は後述するが，今後さらに筋線維の走行に ついて追及する必要性を感した。 上頭, 下頭, および内 側頭の下顎頭長軸に対する角度は上頭は 97.0 度, 下頭は 109.1度, 内側頭は127.7度とそれぞれ有意差をもって見 られ, Honée (1972) ${ }^{19)}$ と同様に上頭より下頭が 矢状面 に対し，急峻であった．また，上下頭が独立分離してい た群と，交錯していた群との間には各筋頭の角度に有意 差は見られなかったが，上下頭が独立分離していた群の 方が上下頭間のなす角度が大きい傾向が見られたことは 外側翼突筋の機能を考える上で重要なことと思われた.

\section{2）側頭筋と外側翼突筋との交錯について}

外側翼突筋は他の咀嚼筋との間に交錯が見られ，内側 翼突筋の前半部で $90 \%$ 以上が，また側頭筋とは50\%以上 が交錯を示し，特に側頭筋との交錯は外側翼突筋上頭と であり，この交錯した側頭筋束は方向をかえて，外側翼 突筋とともに関節裂に停止する。 また側頭筋前部筋束起 始部は側頭下稜を超えて, 側頭下面に及ぶものが $60 \%$ を 占めるといわれている16.

わたくしたちの観察では, 側頭筋と外側翼突筋との交 錯はほとんどが上頭とであり，その交錯する筋線維量は 少ないが24例中12例にみられ, 岩田 (1959) ${ }^{16)}$ の報告に 一致した。 また 1 例において, 外側からの所見で側頭筋 が外側翼突筋のごとく走行し，下顎頭頸部に停止してい たものが見られた，側頭筋前部筋束起始部は側頭骨下面 直下の結合織に存在し，交錯はさらにその下部で見られ たことから，側頭筋との交錯は側頭筋前部筋束起始部と ではなく，側頭筋走行中あるいは停止部と思われたが， その筋線維の追及は困難であった。

\section{3）関節円板に付着する筋について}

外側翼突筋上頭の停止に関する解剖学的報告は比較的 多く見られ，上頭の一部が関節円板に付着し，他は下靧 頸に停止するといらのが一般的である ${ }^{18)}$ また額関節の 発生に関連して, 外側翼突筋の停止部および機能につい て考察している報告が多い. Kjellberg (1904) ${ }^{20)}$ は 55

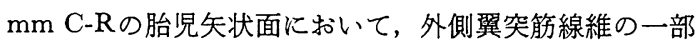
が関節円板に移行していることから関節円板は外側翼突 筋腱に由来するものであるらと記載している. Harpman

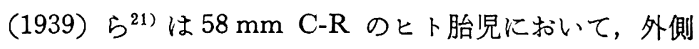
翼突筋線維が下䫁頭原基の内側を通り, さらにその腱膜 が桘骨に続いていることから，関節円板内側は外側翼突 筋腱膜に由来する. また関節円板のこの部分は他の部分 と組織学的に異なっていることを示している. Moffett

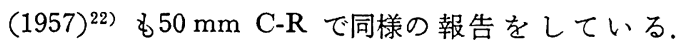


Symons $(1952)^{23)}$ は関節円板および下䫇頭の外形形成に 本筋が関与しているであろうと述べている，また成人に ついては Prentiss (1923) ${ }^{24)}$ は上頭全体が 関節円板に付 着している. Root $(1946)^{25)}$ は上頭が下頭より収縮距離 が短いことから，上頭は開口時に関節円板を前方に牽引 し，下頭が下顎頭を関節結節直下に移動させるのに適し ていると述べている． Sicher (1955) ${ }^{26)}$ は上頭は関節包 と関節円板に付着しこれは移動のための筇ではなく， 下靧頭が関節結節後斜面に前方移動した状態で, 関節円 板が関節結節後斜面に接触させておく役割をするための 働きを有している. Troiano (1967) 2) は22体の外側翼突 筋の筋頭数扰よびその付着部位を経頭蓋法によって検索 し, その結果, 上頭の浅束 (superior slip) は関節円板, 関節包，下頱頭内側に，深束 (deep slip) は関節包内側 に, 下頭は翼突筋窩に, 内側頭は関節包の内側部に停止 すると報告している．Porter $(1970)^{33}$ は42体の外側翼突 筋の関節円板への付着を経頭蓋法によって検索し，その 結果，上頭のほとんとは関節円板の前方部に，一部は関 節円板の前内側と内側に付着し, これら内側の筋線維は 関節円板の内側表面にそって後方部にまでのびている. 下頭は翼突筋窩の内縁にそって関節円板の下縁部にまで 付着する。これにより下顎頭の安定化に効果的で，前方 や後方移動のガイドになる，また関節円板や下顎頭を回 転させるのに適していると述べている，石橋 $(1972)^{27)}$ は上下頭の付着は明確に区分できず，しかもそれらは常 に随伴した協調運動をとるものと推測している. Sicher's Oral Anatomy $(1980)^{18)}$ によれば，外側翼突筋上頭最 上部㧍よび最内側部は関節轿前内側表面に付着し，関節 円板前縁には間接的に付着している，上頭の大部分およ び下頭全体は下顎頸の 翼突筋䈑に入り込んでいる。 た，下㴿を前方移動のみさせる筋は関節蛮と関節円板に 付着し, 後方移動させる筋は下顎骨自体に付着すると述 べている．Pinkert $(1984)^{28)}$ は外側翼突筋は関節円板に は全く着いていないと報告している。

関節円板に付着する他の筋に関する報告は比較的少な く, Edgeworth (1913) ${ }^{29)}$ は哺乳動物の 発生から, 一部 のアザラシの胎児では側頭筋が関節円板, 飭突起, 下顎 頭に付着している。 アザラシでは外側翼突筋は側頭筋と 一体となっており，胎生期においては分離することはな いと述べている. Doyle (1982) ${ }^{30)}$ は $24 \mathrm{~mm} \mathrm{C-R} \mathrm{のヒ}$ 卜胎児において関節円板原基に外側翼突筋上縁之咬筋内 側が付着している. Rees (1954) $)^{31)}$ は側頭筋と咬筋の関 節円板への付着を指摘している．石橋 $(1972)^{27)}$ は咬筇 と関節円板との間に直接の筋線維の連絡は見られない が，咬筇周膜との間に疎性結合織を介して連続性がある ことを示し，さらに側頭筋との間には線維の交流を認め ている. 岩田 $(1959)^{16)}$ は外側翼突筋上頭と交錯した側 頭筋束は方向を変えて, 外側翼突筋とともに関節露に停 止すると述べている.
わたくしたちの観察では，関節円板には外側翼突筋上 頭, 内側頭, 側頭筋が付着しているのが見られた。 その 付着状態は組織学的には確実ではないが, 外側翼突筋上 頭は主に上頭上縁が関節円板中央から内側にかけて円板 の下面に付着し，その一部は下顎頸に停止し，内側頭は 一部円板内側端に直接入り込んでいた。 また，側頭筋は 結合織をもって関節円板前延長部に付着するものや, 直 接関節円板前外側に付着するものが全体の70\%に見られ た。この側頭筋は前あるいは中部筋束と思われたが追及 は困難であった。 下頭は全例ともに下顎頭の翼突筋窩に 停止していた。これらより，外側翼突筋と関節円板との 関係は従来の報告 ${ }^{18)}$ とほとんど違いはなかったが，側頭 筋が関節円板に70\%の高率で付着していたことは, 側頭 筋が関節円板になんらかの関与をしているものと思われ た.

外側翼突筇の名称およびその比較解剖については, 外 側翼突筋上頭，下頭をそれぞれ上腹 (superior belly), 下腹 (inferior belly) と記載しているものもある ${ }^{32}$. し かし，筋組織における “腹” は中間腱を有するものに用 いる名称で，“頭” は起始部において分離しているすの に用いる名称であることから ${ }^{33)}$ ，従来どうり，上頭，下 頭あるいは上部，下部で良いものと思われる。. Prentiss $(1923)^{24)}$ は比較解剖から上頭を sphenomeniscus muscle と呼び，下頭を外側翼突筋と呼んでいる。 また Christensen $(1969)^{10}$ ) は上頭を protrudens menisci と, 下頭 を外側翼突筋と呼ぶことを提案し，Paff (1973) ${ }^{13)}$ は外 側頭と内側頭に分けている. Juniper (1981) ${ }^{34)}$ は CT および䇗電図で外側翼突筋を観察し, その結果, 上頭 を superior pterygoid muscle と命名している. さらに Prentiss (1923) ${ }^{24)}$ は食肉類として猫，草食動物として 牛, 雑食動物として犬の それぞれの 外側翼突筋を観察 し，その結果，これらは external pterygoid muscle す なわち下頭は有せず, sphenomeniscus muscle つまり上 頭のみが存在すると述べている，そしてこの sphenomeniscus muscle はヒトにおける外側翼突筋上頭にあたる。 またヒト型では脳や下顎枝の成長に伴ら顔面の極度の縦 の発育が必要であり, 真の external pterygoid muscle は新しく筋が発達したものであろらと述べている。 Schumacher (1975) ${ }^{35}$ ) は比較解剖の面から各種咀哷筋の 構造と機能について述べている，その中で，外側翼突筋 は食肉類では高度に退化し，1頭筋となり，草食動物 （偶蹄類）や契歯類ではヒトと同じ平行形の 2 頭筋であ ると述べている，神山 $(1958)^{36)}$ は犬において外側翼突 筋はきわめて小さな 1 頭筋で，豚では小さいながら上下 2 頭筋であったと報告している. Scheman $(1967)^{37)}$ は 豚においてヒトと同じ上下 2 頭筋を認め, 河村 (1968) $5^{38)}$ は猫の外側翼突筋は sphenomeniscus muscle であ るがヒトの上頭と同様に, その 9 例中 7 例は下部筋線維 のごく一部は下靧頭の骨膜に付着し，9例中 2 例は筋線 
維の下半分が下顎頭に付着している。 また，この筋の筋 電図学的検索を行い，猫における外側翼突筋は開口時に 活動を示し，閉口時には活動しないことを報告してい る.

外側翼突筋の 組織化学的研究では Maier (1979) ${ }^{39)}$, Katsura (1984) 5 40) らはラットの外側翼突筋を組織化 学的に観察し，その特徵から筋線維を筋疲労が oxdative enzyme activity に相関する region A，および筋疲労に 対し，より耐性を示す region B の 2 つに分類し，それ ぞれが上頭と下頭に一致することから上下頭に機能上の 違いが存在することを示唆している。 また，young rat ではこれら筋線維の区別が困難であるが old rat では容

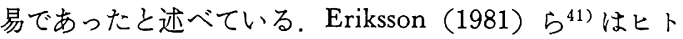
の外側翼突筋の筋線維について組織化学的に検索した結 果, 低い活動間值でゆっくりと持続的に収縮するI型線 維が明らかに優位で，ATPase を介在するIM 型および II C 型が次いで比較的見られ，II A 型は欠如していた. 性差間では I 型の大きさや形態に変化は見られなかっ たが，II型と I M 型の大きさがそれぞれ明らかに異な っている。また，上下頭間で線維の大きさに違いは見ら れないが，線維型の比率に差がある傾向を認め，さらに これらは physical training によって変化することか ら，外側翼突筋は下顎頭を安定させる機能を有すると述 ベている.

外側翼突筋の発生については Symons (1952) ${ }^{23)}$ はヒ

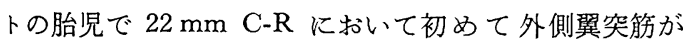
future condylar area に向かって見られ， $30 \mathrm{~mm} \mathrm{C-R}$ で下靧頭が現われ，外側翼突筋がそれに付着する. Moffett (1957) ${ }^{22)}$ はヒトの胎児で $24 \mathrm{~mm} \mathrm{C-Rにおいて}$ は外側翼突筋が下顎骨に付着していることは確認でき ず，関節円板は外側翼突筋の上縁をとうり咬筋の内側縁

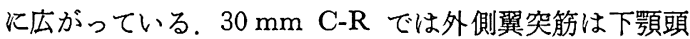
内側に付着するが，さらに下靧頭内側にそって後方に向 かい，関節円板を形成する細胞の帯に結合すると述べて いる.このように下顎頭が形成される前に外側翼突筋が 発生し，しかもそれが前述のごとく関節円板の発生に少 なからず関与しているとすれば，関節円板の由来は別に して，この時期の外側翼突筋が上頭にあたるか下頭にあ たるかが問題になる. Harpman $(1938)^{21)}$ の論文中に拉 いて, $58 \mathrm{~mm}$ C-R の horizontal section の写真上で㐜骨 にまで延びている外側翼突筋の腱膜が翼状突起外側板外 面に起始部を有しているのが見られ，Moffett $(1957)^{22)}$

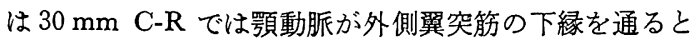
述べている. 一般に顎動脈は下顎頭付近では外側翼突筋 下頭の下を通り，内側に入っている(特に欧州人) ${ }^{42)} こ$ とより，この時期では外側翼突筋は上下頭にはまだ分離 していないものの，上下頭を含んでいるものと考えられ た。また Perry (1985) ${ }^{43)}$ は $130 \mathrm{~mm}$ C-R で外側翼突筋 下頭が下顎頭に着付していることを示しているが，その
原基については触れていない，しかし，外側翼突筋が下 䫵頭と稫骨にそれぞれ付着し，差動牽引をすることで上 下関節腔が作られると報告していることから， $30 \mathrm{~mm}$ C-R での下顎頭内側へ 付着している外側翼突筋から上 頭および下頭が分かれていくものと思われた。また，生 後乳歯萌出前の関節結節は平坦で, 下顎頭の運動も直線 的な前方運動であるが，これが食事の変化を伴った発育 によって乳曾列完成時には関節結節は萌出前の2.1-2.8 倍と顕著になる ${ }^{44)}$. すなわち, 外側翼突筋の発生から外

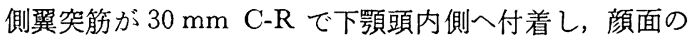
垂直的発育も加わり，上頭および下頭に分かれ，50-60 mm C-R で桘骨に付着し，それぞれ差動牽引をするこ とで上下関節腔が作られる。ささらに, 哺乳行為によって 外側翼突筋下頭の発育がさらに促されていくものと考え られた。このように, 外側翼㔖筋は各種動物における種 属間，年齢差また性差は大きく，乙かもそれらはそれぞ れの環境因子すなわち食性や生活様式によって変化し, それぞれに適応した筋組織の特徴を持つようになり，さ らにはその個体差も大きいものと考えられた。

わたくしたちの観察において筋頭数の違いや，走行中 における筋の交錯が多く見られたことは，上述のごとく 外側翼突筋上下頭が共通の外側翼突筋から発達し, しか も，食性や生活様式の変化に影響されたためと考えられ た。また，各筋頭間に角度が見られたことより，各筋頭 の作用する方向がそれぞれ異なっていることが示され た。しかし上頭，下頭，および内側頭の下䫀頭長軸に対 する角度は上頭は 97.0 度，下頭は 109.1 度，内側頭は 127.7 度とそれぞれ有意差をもって見られたものの，そ の角度差，および等線維の交錯から見て，それぞれが独 立した活動を示すといらより協同して作用すると考えら れた。

最近, ヒトの外側翼突筋の 筋電図学的報告が散見さ れ，その中で，外側翼突筋上頭および下頭が筋電図学的 に異なった活動を示すというもの $32,34,36,45)$, 異なった 活動を示さない46) といら相反する報告が見られる。ま た, Grant (1973) ${ }^{45)}$ はさらに開閉口運動を力学的に分 析し，その運動モーメントから上下 2 頭筋は相反する 2 つの筋として取り扱うことを示している。どちらにせよ その汪とんどの報告者は初めから本筋を解剖学的に独立 分離した上下 2 頭筋として扱い機能を追及している．神 山 $(1958)^{36)}$ は外側翼突筋上頭および下頭が筋電図学的 に異なった活動を示すことを報告したが，その理由の 1 つとして神経支配がそれぞれ独立した別個のものである ことを挙げている.内藤 $(1979)^{17)}$ は55側の成人屍体に おいて下䫇神経の解剖学的研究を行い, その中で, 外側 翼突筋はほとんどが 2 頭筋であるが，3 側に 3 頭筋が見 られた，その神経支配は上頭は94\%が煩神経で，6\%が 下顎神経であり，下頭は67\%が下顎神経で，33\%が下歯 槽神経であった．３頭筋の中頭では煩神経からの枝が分 
布している場合は，上頭の一部筋束が分離している形態 を示し，下顎神経が分布している場合は，下頭の上部 筋束が 分離していたと報告している。 しかし，最近，

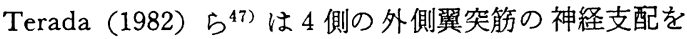
検索し，内藤 $(1979)^{17)}$ の報告に対し，中枢側ではその とおりであるが，遠心部ではしばしば共通の支配を受け る．たとえ1つの筋頭のみを支配していても，筋組織内 では他方の筋に再分布していると述べている，また，咀 嚼筋において加藤 (1966) ${ }^{48)}$ は側頭筋のごとく扁平で各 筋束（前部筋束之 後部筋束）の走行が 全く異なる 筋で は，各筋束間に相反性抑制作用が存在し，しかも各筋束 が全体としても協同して働く。これは Ia 線維による相 反性神経支配によるものであるらと述べている，また， 浜田 (1972) ${ }^{49)}$ はこの抑制現象は Ia 線維による相反性 神経支配の結果ではなく, Golgi 腱受容器の autogenetic inhibition (自己抑制) ${ }^{50}$ ) と同様の神経機序によるもので あ万らと考察している。しかし，ヒトの外側翼突筋には 筋紡鍾はない( ${ }^{51)}$ という報告と存在する ${ }^{52)}$ とい5ものと があり, さらに咀嚼笳中の Golgi 腱受容器についても なお検討中であり ${ }^{53)}$ ，今後の報告に委ねたい，

わたくしたちの観察では，外側翼突筋上頭，下頭，お よび内側頭の下㴿頭に対する角度は上頭は 97.0 度, 下頭 は109.1度，内側頭は127.7度とそれぞれ有意差をもって 見られ，上下頭のなす角度は独立分離していた群が約 18 度, 交錯群が約 8 度と前者が後者より広い角度を有して いた．近接する上下 2 頭筋がそれぞれ同時に異なった活 動様式を示すならば，それぞれは完全に独立した走行を 示さなければならない，この点からいえば，独立分離群 は異なった活動様式を示寸可能性はより大きいものと考 えられた。しかし，上下頭独立分離群ですら上下頭のな す角度は側頭筋の前部筋束と後部筋束のように著しい角 度を有して扣らず，下䫇頭前縁では他の筋頭と交錯して いた。しかも，交錯群では他の笳頭と顕著な交錯を示 し，側頭筋との交錯も高率でみられた。ささらに，近接す る上下 2 頭筋がそれぞれ同時に異なった活動様式を示す には，それぞれが完全に独立した神経支配を受けなけれ ばならない，また外側翼突筋の筋電図学的報告ではその 活動様式は相反性抑制現象様であることから筋線維の交 錯はあまり問題にならないかもしれないが，その交錯の 範囲および程度は，完全な 1 頭筋から内側における交 錯，停止部に扣ける交錯と比較的大きく，内側翼突筋や 側頭筋との 交錯を含め無視することはできないように 思われた。ささらに前述のごとく Prentiss (1923) 24) のい 5 肉食動物にみられる外側翼突筋 (sphenomeniscus muscle）がヒトの外側翼突筋上頭に当たるとすれば，肉 食動物（猫）にみられる蝶番運動では河村 $(1968)^{38)}$ が 述べているように開口運動時のみ活動を示すことから， 外側翼笑筋上頭および下頭が筋電図学的に異なる運動時 に活動を示すといら説には疑問が生じる。また，Mahan
(1983) ${ }^{32}$ は側頭简下にそって翼状突起基底部に誘導ワイ ヤーを刺入しているが，わたくしたちの観察においても 岩田 $(1959)^{16)}$ と同様に翼状突起基底部骨面直下は側頭 筋線維を多く含む結合織，すなわち側頭筋前部筋束起始 部であり，さらに，このように交錯が顕著な平行筋のど の部位から筋電図の採取を行ったかが疑問として残っ た。

これらより，わたくしたちは外側翼突筋の上下 2 頭筋 がそれぞれが機能的に異なった働きを有している可能性 はその走行拉よび筋線維の組織化学的特徵から否定でき ないが，今回の観察の結果およびその神経支配，比較解 剖, 発生の面などから, 外側翼突筋上頭および下頭が筋 電図学的に相反性活動を示すといら報告を支持するもの ではない。

\section{総括および結論}

成人屍体 14 体 26 側を用いて，経頭蓋法による 1）外側 翼突筋の頭数および走行，2）側頭筋と外側翼突筋の交 錯，3）関節円板に付着する筋の観察を行い，機能を含 め, 文献的考察を加えた。 その結果,

1）外側翼突笳が 1 頭筋であったもの 2 例，上頭，下 頭の 2 頭筋であったもの 15 例，外側および内側頭の 2 頭 筋であったもの 1 例, 上頭, 下頭, 内側頭の 3 頭筋であ ったもの 8 例であった。これらのらち，上頭が独立した 走行を示したものは 8 例で, 他は各筋頭間で交錯が影著 であった．外側翼突筇上頭，下頭，および内唄頭の下䫕 頭長軸に対する角度の平均は上頭 97.1 度, 下頭 109.1 度, 内側頭 127.7 度であった。

2 ）側頭筋と外側翼突筋との交錯は上頭とであり，そ の交錯する筋線維量は少ないが24例中12例にみられた。

3 ）関節円板には外側翼突筋上頭, 内側頭, 側頭筋が 付着していた。 その付着状態は組織学的には確実ではな いが，外側翼突筋上頭は主に上頭上縁が関節円板中央か ら内側にかけて円板の下面に付着し，その一部は下顎頭 頸部に停止し, 内側頭は一部円板内側端に直接入り込ん でいた。 また，㑡頭筋は結合織をもって関節円板前延長 部に付着するものや，直接関節円板前外側に付着するも のがみられた。側頭筋と関節円板との間に関連がみられ たものは24例中17例であった。

4）文献的考察などより，外側翼突筋は一般的に二頭 筋であるといら従来の報告には賛同する。しかしその個 体差, 年齢差, 性差および各筋頭間の交錯は大きく, そ れらは食性や生活様式を含む環境因子が筋機能に関与し たためと考えられた。また今回の観察の結果およびその 神経支配, 比較解剖, 筇線維の組織化学的特徵, 発生の 面などから，外側翼突筋上頭および下頭が機能的に異な った働きを有している可能性は否定できないが，上下頭 が筋電図学的に相反性活動を示すといら報告を支持する 
ものではない。

この諭文の要旨は第 39 回日本口腔科学会（昭和 60 年 5 月23日 仙台), 第 6 回顎関節研究会 (昭和 60 年 7 月 6 日東京）に扰いて発表した。

\section{引用 文 献}

1）河村洋二郎：顎関節症の基礎。日遒評論 319: 532-541 1969.

2) Troiano, M.F.: New concept of the insertion of the lateral pterygoid muscle. J Oral Maxillofac Surg 25: 337-340 1967.

3) Porter, M.R.: The attachment of the lateral pterygoid muscle to the meniscus. J Prosthet Dent 24: 555-561 1970.

4) Pinto, O.F.. A new structure related to the temporomandibular joint and middle ear. J Prosthet Dent 12: 95-103 1962.

5) Hoffmann, C.E.E.: Quain's Lehrbuch der Anatomie. 1 Band. Verlag von Eduard Besold, Erlangen, 1870, p 249-252.

6) Chissin, C.: Über die Offnungsbewegung des Unterkiefers und die Beteiligung der außeren Pterygoidmuskeln bei derselben. Arch. f. Anat. u. Entwickelungsgesch. 41-67 1906.

7) Fick, R.: Handbuch der Anatomie und Mechanik der Gelenk unter Berücksichtigung der bewegenden Musklen, Teil 3, Verlag von Gustav Fisher, Jena, 1911, p 1-35.

8) Eisler, E.: Handbuch des Anatomie des Menschen. Band 2, Verlag von Gustav Fischer, Jena, 1912, p 197-234.

9) Choukas, N.C. and Sicher, H.: The structure of the temporomandibular joint. Oral Surg Oral Med Oral Pathol 13: 1203-1213 1960.

10) Christensen, F.G.: Some anatomical concepts associated with the temporomandibular joint. Annals of the Royal Australia College of Dental Surgeons 2: 39-60 1969.

11) Williams, P.L. and Warwick, R.: Gray's anatomy 36 th Ed, Churchill Livingstone, Edinburgh London Melbourne New York, 1980 , p. $534-535$.

12) Basmajian, J.V.: Grant's method of anatomy. 10 th Ed., Williams \& Wilkins, Baltimore, 1980, p. 476-479.

13) Paff, G.H.: Anatomy of the head and neck. Ist Ed, WB Saunders Co, Philadelphia, 1973, p 57-63.

14）中山雄一：支那人の咀嚼筋。満州医誌 17:23361932.

15）鈴木 洋：日本人の咀嚼筋。莯科月報 21：1-6 1941.

16）岩田卓延：日本人深頭筋の解剖学的研究。口腔
解剖研究 12: 323-342 1959.

17）内藤良二：下䫇神経の解剖学的研究。菌科学報 79: 489-540 1979.

18) DuBrul, E.L.: Sicher's Oral anatomy. 7 th Ed, The CV Mosby Co, St Louis, 1980, p 153-154

19) Honée, G.L.J.M.: The anatomy of the lateral pterygoid muscle. Acta Morphol Neerl Scand 10: 331-340 1972.

20) Kjellberg, K.. Beiträge zur Entwicklungsgeschichte des Kiefergelenks. Morphol. Jahrb 32: 159-184 1904.

21) Harpman, J.A. and Woollard, H.H.: The tendon of the lateral pterygoid muscle. J Anat 73: 112-115 1938.

22) Moffett, B.C. Jr.: The prenatal development of the human temporomandibular joint. Contributions to Embryology 243: 19-28 plates 21957.

23) Symons, N.B.B.: The development of the human mandibular joint. J Anat 86: $326-$ 3331952

24) Prentiss, H.J.: Regional anatomy, emphasizing mandibular movements with specific refference to full denture construction. J Amer Dent Ass 10: 1085-1099 1923.

25) Root, R.W.: The mechanics of the temporomandibular joint: illustrated by two cases. Am J Orthod 32: 113-119 1946.

26) Sicher, H.: Structural and functional basis for disorders of the temporomandibular articulation. J Oral Maxillofac Surg 13:275-279 1955.

27）石橋利文：䫑関節の構造に関する顕微解剖学的 研究。茀科基礎医会誌 14：201-222 1972.

28) Pinkert, R.: Die Beziehungen zwischen dem M. pterygoideus lateralis und dem Discus articularis und deren Bedeutung für die Bewegungen im Kiefergelenk. Zahn Mund Kieferheilkd 72: 553-558 1984.

29) Edgeworth, F.H.: On development and morphology of the mandibular and hyoid muscles of mammals. Quart J Micr Sci 59: 573-645 1913.

30) Doyle, D.E.: Embryology and evolution. Diseases of the temporomandibular apparatus. 2nd Ed, edited by Morgan, D.H., House, L.R., and et al. The CV Mosby Co, St Louis, 1982, p 3-7.

31) Rees, L.A.: The structure and function of the mandibular joint. Br Dent J 96:125-133 1954.

32) Mahan, P.E., Wilkinson, B.D.S., et al.: Superior and inferior bellies of the lateral pterygoid muscle EMG activity at basic jaw positions. J Prosthet Dent 50: 710-718 1983.

33) 藤田恒太郎：人体解剖学。第 29 版, 南江堂, 東 
京, 京都, 1981, 105-106頁.

34) Juniper, R.P.: The superior pterygoid muscle. Br J Oral Maxillofac Surg 19:121-128 1981.

35) Schumacher, G.H.: The structure and morphology of human masticating muscles as compared with masticating patterns in various animals. 经田金次郎訳 : 各種動物の咀嚼型か らみたヒトの咀嚼筇の構造と機能. 日菌評論 394: 127-132 1975.

36）神山光男：外側琶笑筋の活動様式に関する研 究. 口病誌 25：576-595 1958.

37) Scheman, P.: Anthropoid comparisons of the anatomy of the external pterygoid muscles of the fetal and adult pig. J Dent Res 46: 1337-1343 1966.

38) 河村洋二郎, 加藤一郎, 他：外㑡翼突筋の形態 と機能に関する研究. 稛基礎誌 10:29-35 1968.

39) Maier, A.: Occurence and distribution of muscle spindles in masticatory and suprahyoid muscle of the rat. Am J Anat 155: 483-506 1979.

40) Katsura, S., Ishizuka, H., et al.: Histochemical studies on the architecture of rat lateral pterygoid muscle. Acta Histochem. Cytochem 17: 59-68 1984.

41) Eriksson, P.O., Eriksson, A., et al.: Special histochemical muscle-fiber characteristics of the human lateral pterygoid muscle. Arch Oral Biol 26: 495-507 1981.

42) 上保䔨彦: 口腔解剖学 (3). 第 1 版, アナトー 么社, 東京, 1966, p 487.

43) Perry, H.T. Xu, Y., et al.: The embryology of the temporomandibular joint. J Craniomandibular Practice 3: 125-132 1985.
44）上條雍彦：咬合を取り巻く形態的要素. 口腔機 能の維持と回復 (1). 日米科評論社, 東京, 1979, p 23-45.

45) Grant, P.G., : Lateral pterygoid: Two muscle? Am J Anat 138: 1-10 1973.

46) Lehr, R.P. and Owens, S.E. Jr.: An electromyographic study of the human lateral pterygoid muscles. Anat Rec 196: 441-448 1980.

47) Terada, S. and Sato, T.: Nerve supply of the medial and lateral pterygoid muscles and its morphological significance. Okajimas Folia Anat Jpn 59: 251-264 1982.

48）加藤一郎：下顎位置調整に関与する顎筇活動. II. 協同筋および拮抗筋よりの求心性信号の役 割. 阪大桏誌 11：125-129 1966.

49）浜田泰三：側頭筋各筋腹の活動を相互に調節寸 る神経機序に関する研究。齿科基礎医会誌 14： 349-359 1972.

50) Grant, R.: Reflex self-regulation of muscle contraction and autogenetic inhibition. J Neurophysiol 13: 351-372 1950.

51) Thilander, B.: Fiber analysis of the lateral pterygoid nerve. Acta Odont Scand 22: 1571631964.

52) Rakhawy, T., Shehata, S.H., et al.: The proprioceptive innervation of the lateral pterygoid muscle in man and some other mammals. Acta Anat 79: 581-598 1971.

53) 河村洋二郎, 浜田泰三: 腱器官からの感覚情 報：顎媈動とそのメカニズム。東京医科菌科大 学歯学部顎口腔総合研究施設編。第 1 版, 日本 婵科評論社, 東京, 1976, 42-48頁. 